\title{
SERUM ANTIPLASMIN AND PLASMIN IN RHEUMATOID ARTHRITIS
}

\author{
BY
}

\author{
D. P. PAGE THOMAS AND J. T. M. DINGLE \\ Rheumatism Research Unit, Area Central Laboratory, Bath
}

(RECEIVED FOR PUBLICATION JANUARY 17, 1955)

The antitryptic activity of rheumatoid serum has been investigated by a number of workers (Coke, 1949; Ragan and others, 1949). Coke has shown that the extent and activity of the disease, in 200 cases of rheumatoid arthritis, was accompanied by an increase in the antitryptic function of serum.

Todd (1949), using streptokinase-activated plasminogen, found a decrease in proteolytic activity during the acute phase of rheumatic fever. The present paper is concerned with alterations in the levels of streptokinase-activated serum plasminogen and serum antiplasmin in rheumatoid arthritis. The serum antiplasmin-plasmin (streptokinase-activated) system was chosen rather than the spontaneous fibrinolytic action of plasma, as the latter has a low degree of activity (Macfarlane and Biggs, 1946; Biggs, Macfarlane, and Pilling, 1947), is labile (Fearnley, Revill, and Tweed, 1952; Truelove, 1953; Fearnley and Tweed, 1953), and is not inhibited by normal plasma (Bidwell, 1953).

\section{Methods}

(1) Measurement of Plasmin Activity.-Patients' sera were obtained with sterile precautions, cooled immediately to $4^{\circ} \mathrm{C}$., and used as soon as possible. The precursor was obtained from the serum by the method of Milstone (1941), 0.5 ml. aliquots of serum being used. This was activated with $0.2 \mathrm{ml}$. streptokinase (equivalent to 200 Christensen units), and incubated for $15 \mathrm{~min}$. at $37^{\circ} \mathrm{C}$.

The proteolytic activity was estimated by a slight modification of the method of Remmert and Cohen (1949), a barbitone- $\mathrm{HCl}$ buffer $(p \mathrm{H} \mathrm{8})$ being used in preference to a phosphate buffer, since this gave greater $p H$ stability. The optimum substrate concentration of 4 per cent. casein found by Rennert was confirmed. Under these conditions the $p \mathrm{H}$ optimum curve gave a sharp peak at
pH 8. A linear relationship was obtained between the enzyme concentration and the acid soluble "Tyrosine" released (Fig. 1-limits 50-200 $\mu$ g. "Tyrosine" per hour).

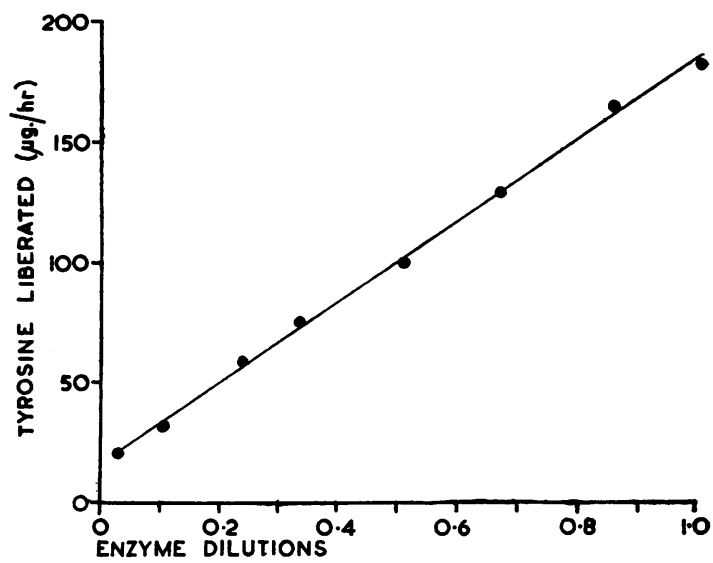

Fig. 1.-Relationship between enzyme concentration and $\mu \mathrm{g}$. acidsoluble "tyrosine" liberated per hour.

(2) Measurement of Antiplasmin.-Plasma, obtained from the blood bank, was used to prepare plasminogen by the method of Milstone (1941). The precursor was prepared in bulk (usually from 2-1. quantities of plasma), dialysed for $24 \mathrm{hrs}$ against distilled water at $4^{\circ} \mathrm{C}$. freeze dried, and stored at $-15^{\circ} \mathrm{C}$.

On each day that antiplasmin estimations were performed, a sample of the precursor was removed, activated with streptokinase, and diluted with barbitone-HCl buffer $(p \mathrm{H} 8)$, to give an activity corresponding to a release of $200 \mu \mathrm{g}$. acid soluble "Tyrosine" per hour at $37^{\circ}$ C. The diluted, streptokinase-activated enzyme, henceforth referred to as the standard enzyme, was used for the measurement of antiplasmin. This was done by adding $0.2 \mathrm{ml}$. of the patient's serum to $0.5 \mathrm{ml}$. standard enzyme and incubating at $37^{\circ} \mathrm{C}$. for $30 \mathrm{~min}$. Estimation of the residual activity was performed as above, and the 
results were expressed as a percentage of the standard enzyme activity (100 per cent. $=200 \mu \mathrm{g}$. acid soluble "Tyrosine" per hour at $37^{\circ} \mathrm{C}$.). A linear relationship was obtained between the serum concentration and the percentage activity (Fig. 2-limits 10-100 per cent. activity).

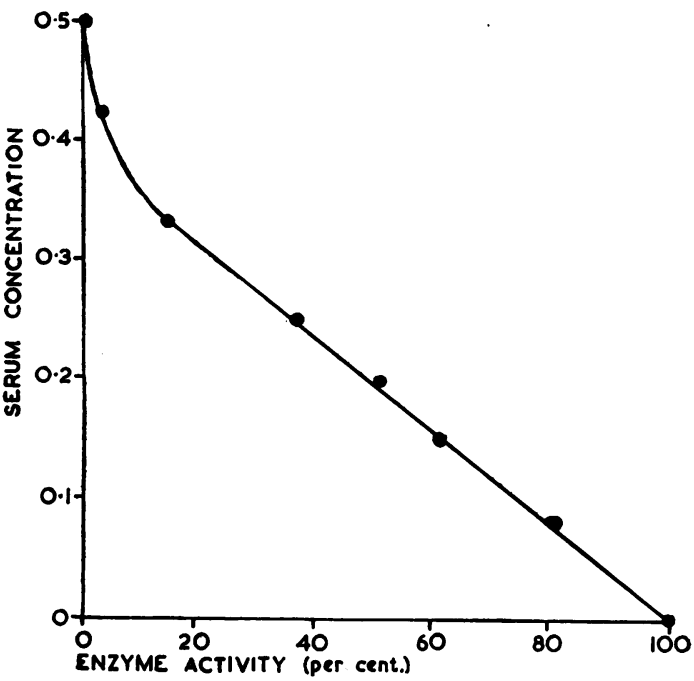

Fig. 2.-Relationship between serum concentration and activity expressed as percentage of a standard enzyme preparation.

\section{Results}

The controls were healthy, ambulant blood donors, fifteen males and thirty females; their ages ranged between 35 and 77 yrs (average 54 yrs).

The cases of rheumatoid arthritis were in-patients at the Royal National Hospital for Rheumatic Diseases, who, at the time of the estimation were being treated by rest and physical measures alone. There were 23 males and twenty females; their ages ranged between 30 and 66 yrs (average 51 yrs).

The streptokinase-activated plasmin and antiplasmin levels could not be correlated with the variation of age and sex in either the control or the rheumatoid groups.

The results of the antiplasmin estimations in 38 controls, and 43 cases of rheumatoid arthritis are shown in Table I, which also shows the variation in antiplasmin activity when correlated with the disease state, as expressed by the erythrocyte sedimentation rate (Westergren).

A significant increase over the control antiplasmin levels is found in cases of rheumatoid arthritis $(P=0.001)$. This increase is most significant in the more active disease states (i.e. sedimentation rate over $50 \mathrm{~mm}$./ hr).

The difference in the proteolytic activity of controls and rheumatoid patients is shown in Table II.
TABLE I

ANTIPLASMIN ACTIVITY OF SERUM OF CONTROL AND RHEUMATOID CASES

RESULTS EXPRESSED AS PERCENTAGE OF STANDARD ACTIVITY

\begin{tabular}{|c|c|c|c|c|c|}
\hline \multirow{3}{*}{ Group } & \multirow{3}{*}{ Control } & \multicolumn{4}{|c|}{ Rheumatoid Arthritis } \\
\hline & & \multirow[t]{2}{*}{ Total } & \multicolumn{3}{|c|}{ Sedimentation Rate } \\
\hline & & & $0-25$ & $25-50$ & $50+$ \\
\hline Number of Cases & 38 & 43 & 10 & 11 & 17 \\
\hline Mean per cent. activity & $83 \cdot 5$ & $66 \cdot 5$ & $71 \cdot 3$ & $68 \cdot 3$ & $58 \cdot 4$ \\
\hline Standard Deviation & 20 & $26 \cdot 1$ & $34 \cdot 1$ & $26 \cdot 9$ & $26 \cdot 9$ \\
\hline $\begin{array}{l}\text { Significance of Variation } \\
\text { between Disease Group } \\
\text { and Controls }\end{array}$ & - & 0.001 & $0 \cdot 20$ & $0 \cdot 05$ & 0.001 \\
\hline
\end{tabular}

TABLE II

PROTEOLYTIC ACTIVITY OF SERUM OF CONTROL AND RHEUMATOID CASES

RESULTS EXPRESSED IN MICROGRAMS ACID-SOLUBLE "TYROSINE" PER HR

\begin{tabular}{|c|c|c|c|c|c|}
\hline \multirow{3}{*}{ Group } & \multirow{3}{*}{ Control } & \multicolumn{4}{|c|}{ Rheumatoid Arthritis } \\
\hline & & \multirow[t]{2}{*}{ Total } & \multicolumn{3}{|c|}{ Sedimentation Rate } \\
\hline & & & $0-25$ & $25-50$ & $50+$ \\
\hline Number of Cases & 45 & 42 & 11 & 12 & 19 \\
\hline Mean Activity .. & 178 & 146 & 134 & 144 & 169 \\
\hline Standard Deviation & 54 & $43 \cdot 2$ & $48 \cdot 9$ & $35 \cdot 4$ & $42 \cdot 8$ 는 \\
\hline $\begin{array}{l}\text { Significance of Variation } \\
\text { between Disease Group } \\
\text { and Controls .. }\end{array}$ & - & 0.01 & 0.02 & 0.05 & $0 \cdot 50 \frac{\overline{\frac{9}{7}}}{7}$ \\
\hline
\end{tabular}

There was a significant decrease in plasmin activity in the rheumatoid cases. Contrary to the antiplasmin findings this decrease in proteolysis bore no definite relation to increased disease activity as expressed by the erythrocyte sedimentation rate.

\section{Comment}

Plasmin is one of the main proteolytic enzymes present in blood, and it has been shown to be less sensitive than trypsin to inhibition by serum (Surgenor and others, 1953; Müllertz, 1953). Thus it would seem possible for serum antitryptic levels to be raised without a measurable increase in antiplasmin activity.

Coke found that the antitryptic activity of serum increased with the severity of the disease in rheumatoid arthritis. Though plasmin is less sensitive than trypsin to inhibition by serum, our results show a rise in antiplasmin levels with an increase in the severity of the disease. Thus both inhibitors show a similar rise which can be correlated with the state of the disease. It is of interest, however, that Hammarsten and Jonsson (1954), using chloroform- 
activated plasmin preparations, the activity of which was measured by fibrin clot lysis, found no change in either enzyme or anti-enzyme levels in cases of rheumatoid arthritis.

Increase in the serum inhibitor of trypsin was also found by Shulman (1952) to be associated with diseases characterized by tissue destruction. $\mathrm{He}$ found that the change in the inhibitor was closely correlated with the sedimentation rate. Holmes and others (1935) reported antitryptic activity in synovial exudates, and suggested that it might prevent tissue damage by protease, liberated from accumulated leucocytes.

As a result of the acute phase of inflammation in the proliferating synovium, fibrinogen makes its appearance in the synovial fluid (Ropes and Bauer, 1953), and this is deposited as fibrin which has plasmin adsorbed on to it (Bidwell, 1953). If no defence mechanism is present, the enzyme is able to lyse the fibrin, and so interfere with the attempt at self-limitation of the inflammation. Increased antiplasmin levels in the serum of rheumatoid arthritis might reflect such a defence process. Thus our findings of increased antiplasmin values in this disease lend support to views on the possible importance of the serum inhibitor. In considering the physiological aspects of this increase, however, the non-specific nature of the response must be taken into account (Burdon, 1950; Guest and others, 1948; Jensen, 1953).

The lowered serum plasmin levels found in cases of rheumatoid arthritis would, at first sight, seem to reciprocate with the increased antiplasmin levels reported; this is not the case, as the lowest proteolytic levels were found in the groups in which the disease was least active; a finding which is quite contrary to the antiplasmin values.

\section{Summary}

Estimations of serum plasmin and antiplasmin were carried out in 43 cases of rheumatoid arthritis and 38 control cases.

Serum antiplasmin levels were found to be increased in rheumatoid arthritis, and to vary with the severity of the disease.

Serum plasmin levels appeared to be reduced in rheumatoid arthritis, but were unrelated to the state of the disease as expressed by the sedimentation rate.
We wish to thank Dr. G. D. Kersley for his advice and encouragement, Dr. M. R. Jeffrey for his help in the collection of blood samples at the Royal National Hospital for Rheumatic Diseases, Dr. C. D. Cross of St. Martin's Hospital Blood Bank, Bath, and Mr. P. Tomey for technical assistance.

\section{REFERENCES}

Bidwell, E. (1953). Biochem. J., 55, 497.

Biggs, R., Macfarlane, R. G., and Pilling, J. (1947). Lancet, 1, 402. Burdon, K. L. (1950). Fed. Proc., 9, 378.

Coke, H. (1949). Annals of the Rheumatic Diseases, 8, 135.

Fearnley, G. R., Revill, R., and Tweed, J. M. (1952). Clin. Sci., 11, 309 .

and Tweed, J. M. (1953). Ibid., 12, 81.

Guest, M. M., Daly, B. M., Ware, A. G., and Seegers, W. H. (1948). J. clin. Invest., 27, 793.

Hammarsten, C., and Jonsson, E. (1954). Acta med. scand., 147, 359. Holmes, W. F., Keefer, C. S., and Myers, W. K. (1935). J. clin.

Jensen, H., Chamovitz, D. L., Volkringer, E., Gray, E., Gosney, J. E., and Kocholatz, W. (1953). Blood, 8, 324.

Macfarlane, R. G., and Biggs, R. (1946). Lancet, 2, 862.

Milstone, H. (1941). J. Immunol., 42, 109.

Müllertz, S. (1953). Acta physiol. scand., 28, 29.

Ragan, C., Grokoest, A. W., and Boots, R. H. (1949). Amer. J. Med., 7,741 .

Remmert, L. F., and Cohen, P. P. (1949). J. biol. Chem., 181, 431

Ropes, M. W., and Bauer, W. (1953). "Synovial Fluid Changes in Joint Disease," Harvard University Press, p. 52.

Shulman, N. R. (1952). J. exp. Med., 95, 605.

Surgenor, D. M. Hunter, M. J., and Brown, R. K. (1953). In "Blood Cells and Plasma Proteins," ed. J. L. Tullis, p. 315. Academic Press, New York.

Todd, E. W. (1949). J. exp. Med., 89, 295.

Truelove, S. C. (1953). Clin. Sci., 12, 75.

\section{Antiplasmine sérique et plasmine dans l'arthrite rhumatismale}

RÉSUMÉ

On a effectué le dosage de la plasmine et de l'antiplasmine sérique chez 43 malades atteints d'arthrite rhumatismale et chez 38 témoins.

On a trouvé que le taux de l'antiplasmine sérique était augmenté dans l'arthrite rhumatismale et qu'il variait avec la sévérité de la maladie.

Le taux de la plasmine sérique paraissait diminué dans l'arthrite rhumatismale mais ne se rapportait pas à l'état de la maladie exprimé par la vitesse de la sédimentation érythrocytaire.

\section{Antiplasmina sérica y plasmina en la artritis reumatoide \\ SUMARIO}

Se determinaron las tasas de la plasmina y de la antiplasmina sérica en 43 enfermos con artritis reumatoide $y$ en 38 testigos.

Se encontró que las cifras de la antiplasmina sérica fuéron aumentadas en la artritis reumatoide y variables según la severidad de la enfermedad.

La cifras de la plasmina sérica parecían reducidas en la artritis reumatoide pero sin relación con el estado de la enfermedad reflejado en la velocidad de la sedimentación eritrocitaria. 